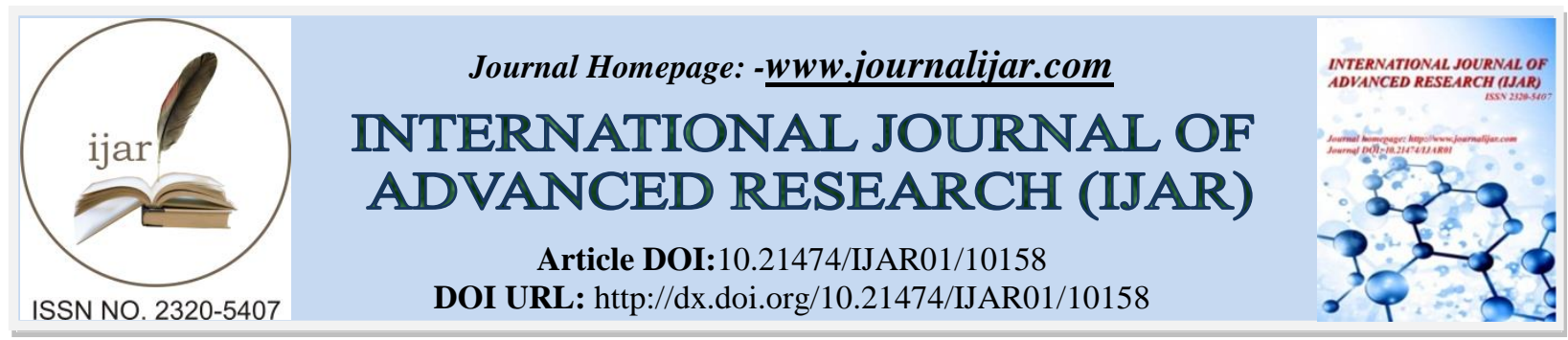

RESEARCH ARTICLE

\title{
ANATOMICAL STUDIES ON THE NERVUS VAGUS OF ALTICUS KIRKIIMAGNUSI (KLAUSEWITZ, 1964).
}

Ahmed Imam Dakrory ${ }^{1}$ and Rania Sayed $\mathrm{Ali}^{2}$.

1. Zoology Department, Faculty of Science, Cairo University.

2. Zoology Department, Faculty of Science, Helwan University.

\section{Manuscript Info}

……………………

Manuscript History

Received: 03 October 2019

Final Accepted: 05 November 2019

Published: December 2019

Key words:

Alticus kirkiimagnusi- Nervus vagus cranial nerves.

\begin{abstract}
In Alticus kirkii studied the nervus vagus arises from the brain by one root and leaves the cranial cavity through the jugular foramen. The intracranial dorsal cutaneous vagal ramus has its own ganglion. It carries all the somatic sensory fibres of the vagus nerve. The vagus nerve has a single lateral jugular (epibranchial) ganglion. The first vagal branchial trunk lacks the ramus pharyngeus and the third one lacks the ramus pretramaticus. The nervus vagus anastomoses twice with the cranial sympathetic nerve. The nervus vagus carries general somatic sensory fibres to the skin, general viscerosensory fibres to the pharyngeal epithelium, special viscerosensory fibres to the gill rackers and the taste buds and visceromotor fibres to the levators and the adductor arcuales branchiales and the obliquus ventrales muscles of the second, third and fourth holobranchs, as well as to the transverses dorsalis and ventralis muscles. It also carries vegetative fibres (parasympathetic) for the blood vessels, thyroid glands and the muscles of the gill filaments.
\end{abstract}

Copy Right, IJAR, 2019,. All rights reserved.

\section{Introduction:-}

Blenniidae is a highly diverse family of teleosts, which includes 57 genera and 387 species worldwide (Hastings and Springer 2009; Nelson et al., 2016) or 406 species (Mehraban and Esmaeili, 2018). Blennies occur mainly in marine habitats, including the intertidal zone (Aizawa and Doiuchi, 2013), along with a few species known from fresh and/or brackish water (Mehraban and Esmaeili, 2018). Some intertidal blenniids are known as highly mobile skippers (Martin 2014).

The members of the family Blenniidae have been studied almost exclusively for their taxonomy (Gilbert, 1891; Hubbs, 1952; Nelson et al., 2016; Alavi-Yeganeh et al., 2018; Mehraban and Esmaeili, 2018), morphology, distribution and conservation status (Smith 1959 a \&b; Stevens and Parsons 1980; Wright et al. 1990; Abou-Seedo 1992; Springer and William, 1994; Randall, 1995; Smith-Vaniz et al., 2001; Mehraban and Esmaeili, 2018), physiological and morphological (gill and skin) characteristics (Brown et al., 1992), feeding behavioral and ecology(Clark, 1936; Curio, 1968; Brown et al., 1991, Nieder, 2001). Howe (1991) investigated the surface structure of its eggs. Few anatomical studies as the unique eye structure (Breder and Gresser, 1940; Munk, 1970; Stevens and Parsons, 1980).

Corresponding Author:-Ahmed Imam Dakrory.

Address:-Zoology Department, Faculty of Science, Cairo University. 
Morphologically, the gills of amphibious fish are generally more sturdily built, thicker, and have fewer secondary lamellae than their aquatic counterparts (Hughes, 1984; Hughes and Morgan, 1973; Graham, 1976). The usual explanation for this morphology is that the gills must resist collapse in air. Even so, they must still be able to function in water, where oxygen availability is substantially lower (Dejours, 1981).

Important behavioral characteristics that help the amphibious rock skipper blenny of the Red Sea, Alticus kirkimagnusi, to survive and thrive at the land-water interface are described by Brown et al. (1991). The physiological and morphological (gill and skin) characteristics of Alticus relevant to aerobic respiration in both environments are studied by Brown et al. (1992), the skin characteristics and organization (Harabawy and Mekkawy, 2011). The sensory systems of Alticus kirkiimagnosi (receptors, their nerves as well as their centres) play a major and sometimes a decisive role in many fish behavioral patterns (feeding, defense, spawning, schooling orientation, etc...).

Functionally, the vagus nerve is mixed nerve. The nature and relation of the vagal nerve fibres in fishes have attracted the attention of anatomists a long time ago (Norris, 1925; Saxena, 1967; Herrick, 1901; Maheswari, 1965; Northcutt and Bemis, 1993; Hussein, 2010). The anatomical literatures recorded obvious differences about the number of the vagal roots and their exit from the cranial cavity (Handrick, 1901; Norris, 1925; Saxena, 1967; Lazar et al., 1992; Northcutt and Bemis, 1993; Piotrowski and Northcutt, 1996; Dakrory, 2000; Ali, 2005; Dakrory and Ali, 2006; Hussein, 2010; Matter, 2012). Again, the number and position of the vagal ganglia (jugular or epibranchial and intracranial) is a matter of contradiction (Allis, 1903\& 1922; Herrick, 1901, Northcutt and Bemis, 1993; Piotrowski and Northcutt, 1996; Dakrory, 2000; Ali, 2005; Lazar et al., 1992; Dakrory and Ali, 2006; Matter, 2012). Also, the developmental state and the number of rami of this nerve show great differences among studied species. Furthermore, the relations of the vagal nerve with the other cranial nerves show different opinions among anatomists (Allis, $1909 \&$ 1922; Saxena, 1967; Lehn, 1918; Dakrory, 2000; Ali, 2005; Dakrory and Ali, 2006; Hussein, 2010; Ali, 2012; Dakrory, et al., 2012).

It is clear from the available literature on the cranial nerves of teleosts that there are nearly no investigations were performed on the members of family Blenniidae. The only known study is that on the eye-muscle nerves of Alticus kirkii magnusi (Ali and Dakrory, 2008). Generally in fishes, early studies were done by some authors on cranial nerves of bony fishes (Allis, 1909 \& 1922; Herrick, 1900 \& 1901). The cranial nerves of some teleosts were studied by some authors such as Freihofer (1978) on Polypterus schomburgkii, Harrison (1981) on Trichiurus lepturus, Northcutt and Bemis (1993) on Latimeria chalumnae, Piotrowski and Northcutt (1996) on Polypterus senegalus, Dakrory (2000) on Ctenopharyngodon idellus, Ali (2005) on Tilapia zillii, Nakae and Sasaki (2006) on Mola mola, Hussein (2010) on Mugil cephalus, Taha (2010) on Hypophthalmichthys molitrix, Al-Harthi (2016) in Liza aurata and Almalki (2017) in Oreochromis niloticus.

Other studies were performed on one cranial nerve or a group of cranial nerves in some other bony fishes. Kassem et al. (1988) and Bauchot et al. (1989) gave an account on the eye muscles nerves in Chaetodon trifasciatus and Tridentiger trigonocephalus, respectively. In addition, De Graaf (1990) studied the innervation of gills in Cyprinus carpio by dissection. The most recent studies performed on bony fishes are presented by some other authors such as Dakrory (2003) who studied the ciliary ganglion and its anatomical relations in some bony fishes. In addition, Ali and Dakrory (2008) studied the eye muscle nerves of this species; Dakrory et al. (2018a\&b) studied the eye muscle nerves and the nevus glossopharyngeus of Garra tibanica.

It is evident from the aforementioned historical review that there are numerous works on the cranial nerves of fishes, but nearly no studies had been made concerning the cranial nerves of Blinniidae. Although the previously mentioned studies of different authors may threw light on the subject of the cranial nerves of fishes, yet it cannot be stated that the cranial nerves of a Blinniidae is similar to other fishes; and what are the differences if present? Thus it was suggested that a detailed microscopic study on the vagal nerve in Alticus kirkii magnusi will be very useful. The main and fine branches of this cranial nerve, its distribution, its relation with other nerves and with the other structures of the head, its analysis and the organs they innervate are studied thoroughly, hoping that it may add some knowledge on this important subject and also to the behaviour and phylogeny of this group of fishes.

\section{Material And Methods:-}

The specimens of the rock skipper fish, Alticus kirkiimagnosi (family: Blenniidae ; order: Blinniiformes ) were captured from the Red Sea at Ras Mohamed, Sharm El-Sheihk, South of Sinai during March 2008. 
This is a marine primarily tropical fish (Aizawa and Doiuchi, 2013; Mehraban and Esmaeili, 2018); the body is naked without scales, the head is blunt and the pelvic fins lie anterior to the pectoral ones; the palate is toothless and jaws have comb-like fixed teeth (Randall, 1995). The adult fish has no swim bladder but has a basisphenoid bone (Randall, 1995). This species is oviparous and the ggs are demersal and adhesive (Breder and Rosen, 1966), and are attached to the substrate via a filamentous, adhesive pad or pedestal and the Larvae are planktonic, often found in shallow, coastal waters (Watson, 2009).

Adults are found in the intertidal zone of exposed rocky shores, often out of the water (Randall, 1995). They actively shuttle back and forth between rock pools and air (skipper) (Martin and Bridges, 1999).Breathe air when out of water (Martin and Bridges, 1999). It is oviparous (Breder and Rosen, 1966), the eggs are demersal and adhesive (Breder and Rosen, 1966), and are attached to the substrate via a filamentous, adhesive pad or pedestal (Watson, 2009). Larvae are planktonic, often found in shallow, coastal waters (Watson, 2009).

Heads of these specimens were cut and fixed in aqueous Bouin's solution for 24 hours. They were then washed several days with $70 \%$ ethyl alcohol. The specimens were decalcified using EDTA solution for three to four weeks, changing the solution every four days. The heads were then dehydrated, cleared, mounted and embedded in paraffin wax and serially sectioned transversally at 10 micrometers thick. After sectioning, the serial sections were mounted and stained with triple Malory stain (Pantin, 1946).

The serial sections were drawn with the help of a projector. From these sections an accurate graphic reconstruction for the vagus nerve was made in a lateral view. Parts of some selected sections were photomicrographed to show the position of the vagus nerve and its relation to the other cranial structures.

\section{Results:-}

In Alticus kirkii studied, the nervus vagus originates from the mid-lateral side of the medulla oblongata by a single stout root. This root (Figs. $1 \& 2$, RO. X) arises from the medulla oblongata posterior and ventral to the origin of the posterior lateral line nerve. It runs posterior in the ventrolateral direction, passing lateral to the medulla oblongata (MO) and medial to the ganglion of the intracranial dorsal vagal ramus. Here, it gives off a lateral nerve, which is the intracranial dorsal vagal ramus (Figs. $1 \& 2$, RO. ICDV). This ramus will be described shortly latter on. Posterior to the origin of this branch, the nervus vagus continues passing lateral to the medulla oblongata and medial and then ventromedial to both the ganglion of theintracranial dorsal vagal ramus and the posterior lateral line nerve. Thereafter, it shifts posteroventrally to leaves the cranial cavity together with and medial to the posterior lateral line nerve by penetrating the meninx primitive through the jugular foramen. The later foramen is in the form of incisura and lays medial to the opisthotic bone (OP. OT) and lateral to the exoccipital one (EO) (Fig. 3, F. JU).

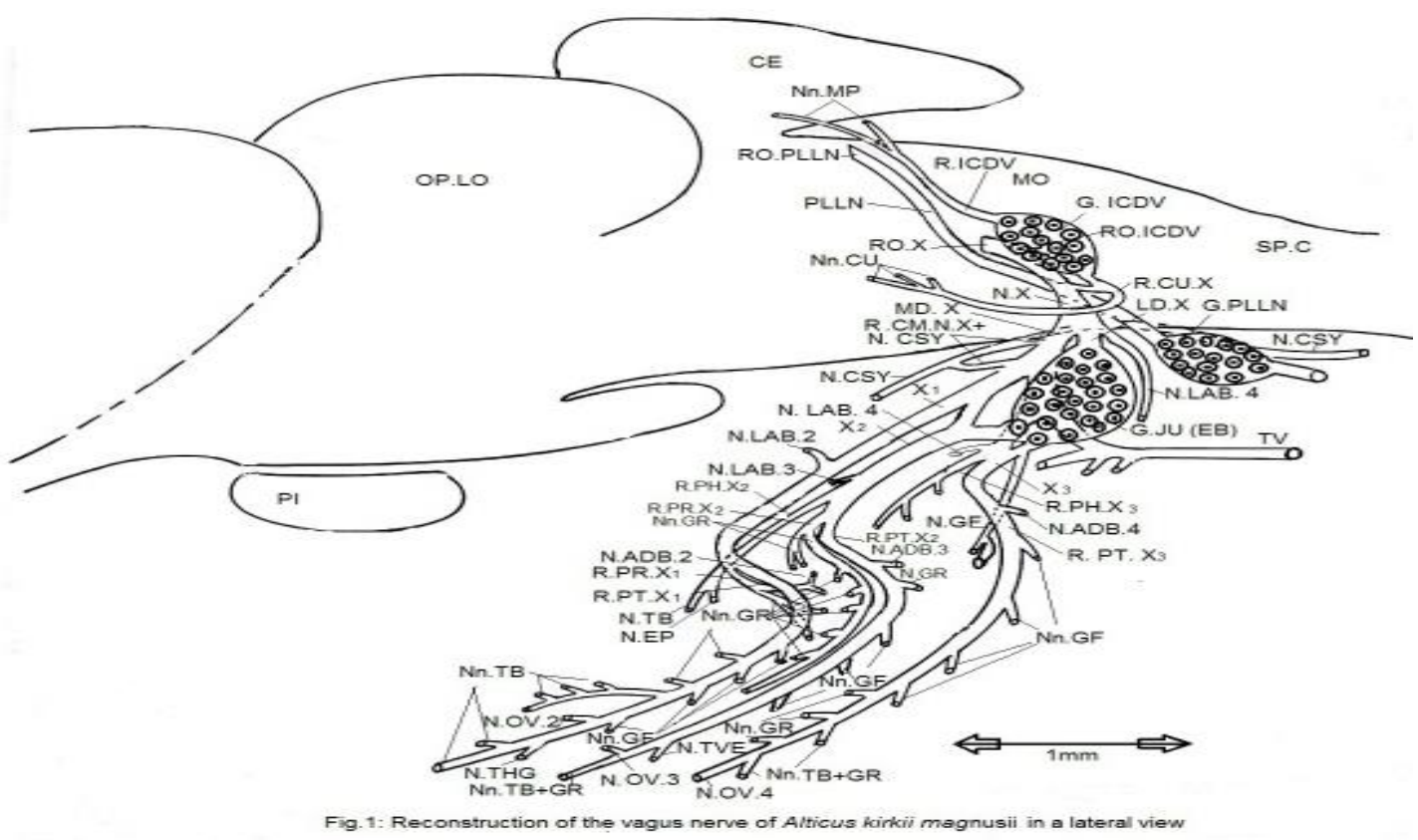


CE: Cerebellum, G. ICDV: Intracranial dorsal vagal ganglion, G. JU: Jugular ganglion, G. PLLN: Posterior lateral line ganglion, LD. X: Lateral division of vagal nerve, MD. X: Median division of vagal nerve, MO: Medulla oblongata, N. ADB. 2: Second adductor arcus branchialis nerve, N. ADB. 3: Third adductor arcus branchialis nerve, N. ADB. 4: Fourth adductor arcus branchialis nerve, N. EP: Nerve for epithelium, N. GF: Nerve for the gill filament, N. GR: Nerve for gill rackers Nerve for gill rackers, N. LAB. 2: Nerve for the second levator arcus branchialis muscle, N. LAB. 3: Nerve for the third levator arcus branchialis muscle, N. LAB. 4: Nerve for the fourth levator arcus branchialis muscle, N. OV. 2: Nerve for the second obliquus ventralis muscle, N. OV. 3: Nerve for the third obliquus ventralis muscle, N. OV. 4: Nerve for the fourth obliquus ventralis muscle, N. CSY: Cranial sympathetic nerve, N. TB: Nerve for taste buds, N. TD: Nerve for transversus dorsalis muscle, N. THG: Nerve for thyroid gland, N. TVE: Nerve for transversus ventralis muscle, N. X: Nervus vagus, Nn. CU: Cutaneous nerves, Nn. GF: Nerves to gill filaments, Nn. GR: Nerves to gill rackers, Nn. TB+GR: Nerves for taste buds and gill rackers, Nn. MP: Nerves for meninx primitive, Nn. TB: Nerves for taste buds, OP. LO: Optic lobe. PI: Pituitary gland, PLLN: Posterior lateral line nerve, R. CU. X: Cutaneous ramus of vagal nerve, R. CM. N. X+N. CSY:Ramus communicance between vagal nerve and cranial sympathetic nerve, R. ICDV: Intracranial dorsal vagal ramus, RO. ICDV: Intracranial dorsal vagal root, RO. PLLN: Root of the posterior lateral line nerve, RO. X: Vagal root, R.

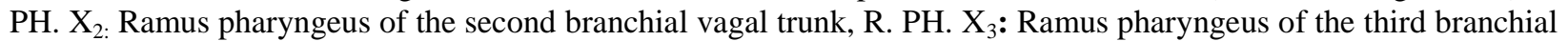
vagal trunk,R. PR. $\mathrm{X}_{1}$ : Ramus Pretrematicus of the first branchial vagal trunk, R. PR. $\mathrm{X}_{2}$ : Ramus Pretrematicus of the second branchial vagal trunk, R. PT. $X_{1}$ : Ramus posttrematicus of the first branchial vagal trunk, R. PT. $X_{2}$ : Ramus posttrematicus of the second branchial vagal trunk, R. PT. $\mathrm{X}_{3}$ : Ramus posttrematicus of the third branchial

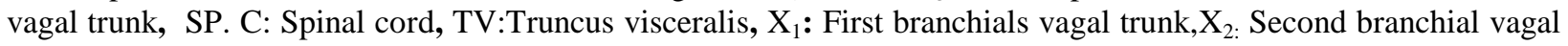
trunk, $\mathrm{X}_{3}$ : Third branchial vagal trunk.

\section{Intracranial Dorsal Cutaneous Vagal Ramus:-}

Directly after its separation from the root of the nervus vagus, the intracranial dorsal cutaneous vagal ramus (Figs. 1 \& 2, RO. ICDV), enters its own ganglion (Figs. 1 \& 2, G. ICDV). This ganglion is an oval shaped collection of large ganglionic cells, located intracranially (Fig. 2, G. ICDV). It ends posteriorly at the anterior orifice of the jugular foramen. From this ganglion arise two nerves; one from its anterodorsal extremity and the other from its ventrolateral side. The anterodorsal nerve (Fig. 1, R. ICDV) extends forwards in a dorsal direction, within the cranial cavity, being medial to the membranous labyrinth and lateral to the medulla oblongata. Here, it gives off two fine nerves that ramify and end in the meninx primitiva that protects the brain in this region (Fig. 1, Nn. MP.). Thereafter, the anterodorsal nerve continues anterodorsal to leave the cranial cavity through the parietal bone and ramifies and ends as fine nerves in the skin of postotic region.

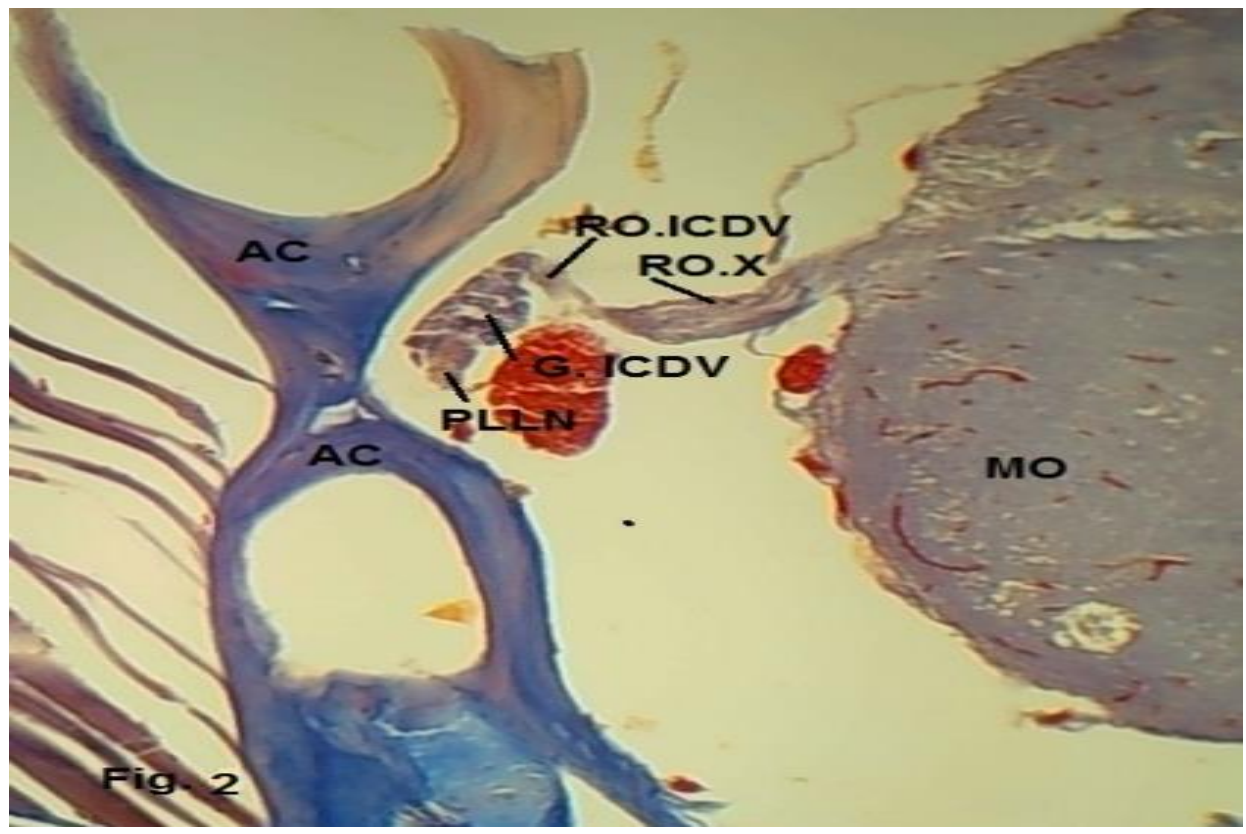

Fig. 2:- Photomicrograph of a part of a transverse section of Alticus kirkii magnusi passing in the postotic region shows the vagal root, the root of the intracranial dorsal vagal ramus and the intracranial dorsal vagal ganglion. X40. 


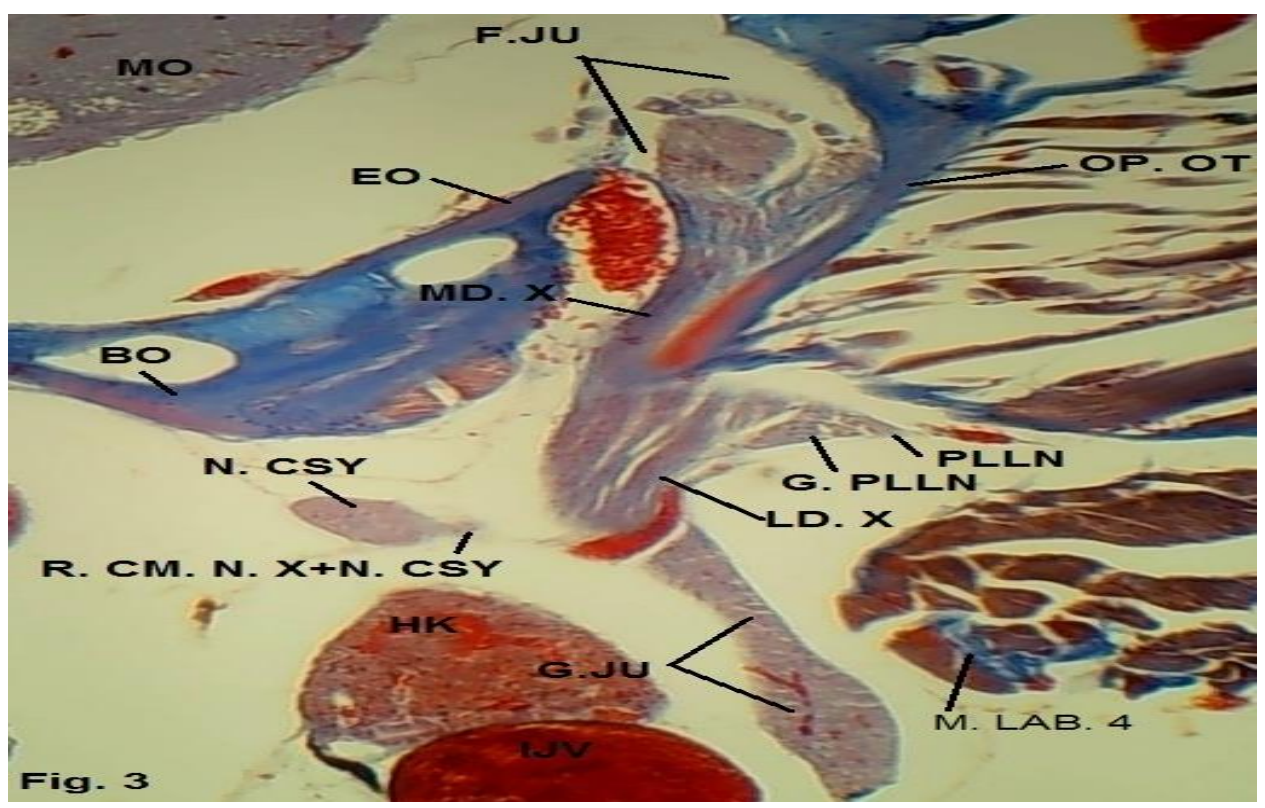

Fig. 3:-Photomicrograph of a part of a transverse section of Alticus kirkii magnusi passing in the postotic region illustrating the position of both the jugular foramen and jugular ganglion (epibranchial ganglion), the lateral and medial vagal divisions and the ramus communicans between the nervus vagus and the cranial sympathyetic nerve. $\mathrm{X}$ 40.

AC: Auditory capsule, BO: Basioccipital bone, EO: Exoccipital bone, F.JU: Jugular foramen, G.ICDV: Intracranial dorsal vagal ganglion, G.PLLN: Posterior lateral line ganglion, HK: Head kidney, IJV: Internal jugular vein, LD.X: Lateral division of vagal nerve, M.LAB.4: Fourth levator arcus branchialis muscle, MD.X: Median division of vagal nerve, MO: Medulla oblongata, N.CSY: Cranial sympathetic nerve, OP.OT: Opisthotic bone, PLLN: Posterior lateral line nerve, R. CM. N. X+N. CSY: Ramus communicance between vagal nerve and cranial sympathetic nerve, RO.ICDV: Intracranial dorsal vagal root, RO.X: vagal root.

The posteroventral nerve (Fig. 1, R. CU. X), which arises from the venterolateral side of the ganglion, extends posterolaterally leaving the cranial cavity through the jugular foramen. While passing through this foramen, it receives a branch of the posterior lateral line nerve. Extracranially, this nerve extends laterally ventral to the dorsal spinal muscles, and then turns anteriorly dorsolaterl to the later muscles where it ramifies and ends in the skin of the postotic and the temporal region (Fig. 1, Nn. CU).

Shortly, after its exit from the cranial cavity, the nervus vagus divides into lateral (LD. X) and medial (MD. X) divisions (Figs. 1\& 3). The lateral division (Figs. 1\& 3, LD. X) gives off a lateral fine motor branch to the fourth levator arcus branchialis muscle (Figs. 1\& 4, N. LAB. 4), and then enters the jugular ganglion (Figs. 1, 3\& 4, G. JU). The later ganglion is an oval shape collection of ganglionic celles. It is located (Figs. 3\& 4) medial and ventromedial to the fourth levator arcus branchialis muscle (M. LAB. 4), dorsolateral to the internal jugular vein (IJV) and lateral to the head kidney (HK).

The medial vagal division (Figs. 1, 3\& 4, MD. X) extends forwards dorsal to the jugular ganglion and divides into a ventral and dorsal stout bundles. The ventral bundle divides into medial nerve which is the truncus visceralis (Figs. $1 \& 4, \mathrm{TV})$ and lateral one which fuses with the third vagal branchial trunk shortly forwards after its origin from the jugular ganglion. The dorsal bundle gives off an anastomosing branch to the cranial sympathetic nerve (Figs. $1 \& 3$, R. CM. N. X+N. CSY). Shortly anterior the dorsal bundle give raise a ventral branch, which fuses with the second branchial vagal trunk anterior to its origin from the jugular ganglion. The remainder of this dorsal bundle forms the first branchial vagal trunk. The visceral trunk is out of our scope in this study. From the anteroventral end of the jugular ganglion arise the second $\left(\mathrm{X}_{2}\right)$ and third $\left(\mathrm{X}_{3}\right)$ branchial vagal trunks (Fig. 1). 


\section{First Branchial Vagal Trunk " $X_{1}$ ":-}

In the blenniid species studied, the first branchial vagal trunk (Figs. 1, 5\& 6, $\mathrm{X}_{1}$ ) extends forwards for a long course passing dorsal to the jugular ganglion, lateral to the cranial sympathetic nerve and dorsolateral to the internal jugular vein. Here, it anastomoses with the cranial sympathetic nerve by a fine anastomosing branch (Fig. 1, R. CM. N. X + $\mathrm{N}$. CSY). Thereafter, this trunk continues anteriorly passing dorsal to the second branchial vagal trunk, lateral to the internal jugular vein and medial to the third levator arcus branchialis muscle. More forwards, it becomes ventrolateral, ventral and then ventromedial to the internal jugular vein, dorsomedial and medial to the later muscle, dorsolateral to the third efferent branchial vessel and lateral to the second branchial vagal trunk. Here, it gives off a motor nerve to the second levator arcus branchialis muscle (Fig. 1, N. LAB. 2). Shortly anterior, it enters the second holobranch, just ventromedial to the fusion of the second efferent branchial vessel with the circus cephalicus. Here, it divides into a small, ventromedial ramus pretrematicus $\mathrm{X}_{1}$ (Figs. 1\&7, R. PR. $\mathrm{X}_{1}$ ) and a large dorsolateral ramus posttrematicus $\mathrm{X}_{1}$ (Figs. 1\&7, R. PT. $\mathrm{X}_{1}$ ). It also gives a motor nerve to the second adductor arcus branchialis muscle (Fig. 1, N. ADB. 2).

\section{Ramus Pretrematicus Of $\mathrm{X}_{1}$ :-}

After its separation from the ramus posttrematicus $\mathrm{X}_{1}$, this ramus (Figs. $1 \& 7$, R. PR. $\mathrm{X}_{1}$ ) extends posteroventraly running ventromedial to the second epibranchial bone and dorsolateral to the second adductor arcus branchialis muscle. Here, it gives off a fine nerve to the later muscle. Thereafter, the main ramus penetrates the muscle to become lateral to the pharyngeal cavity and ramifies to innervate the pharyngeal taste buds. One or more of these ramification pass to the gill rackers dorsal to the second ceratobranchial bones of the holobranch.

\section{Ramus Posttrematicus $\mathbf{X}_{1}$ :-}

After its separation from the pretrematic ramus $X_{1}$, the posttrematic ramus (Figs. 1\&7, R. PT. $X_{1}$ ) extends posteroventrally dorsolateral to the second epibranchial bone and medial to the efferent branchial vessel. Here, it gives off fine branches to the gill filaments. Thereafter, it shifts anteriorly to become ventrolateral to the second ceratobranchial cartilage giving rise

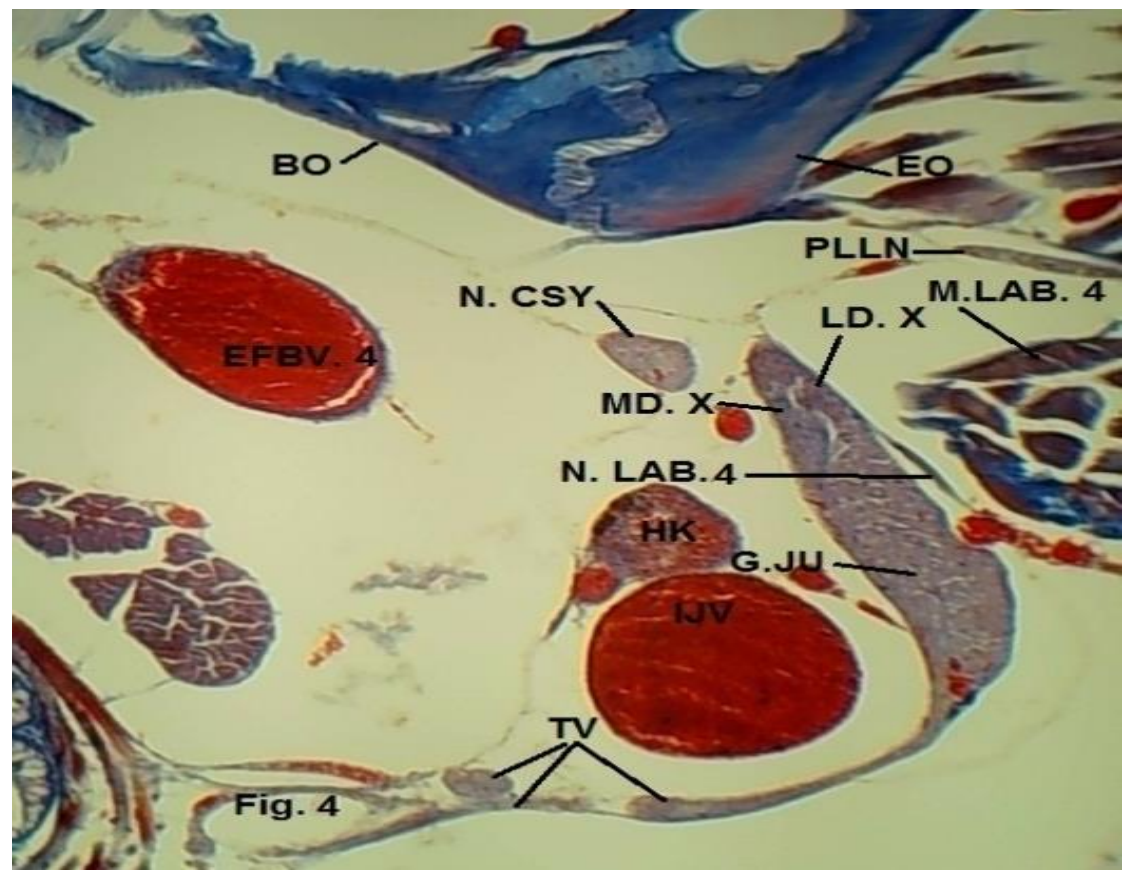

Fig. 4:- Photomicrograph of a part of a transverse section of Alticus kirkii magnusi passing in the postotic region demonstrating the position of the truncus visceralis and the shape and position of the jugular ganglion and the lateral and medial vagal division. X 60 


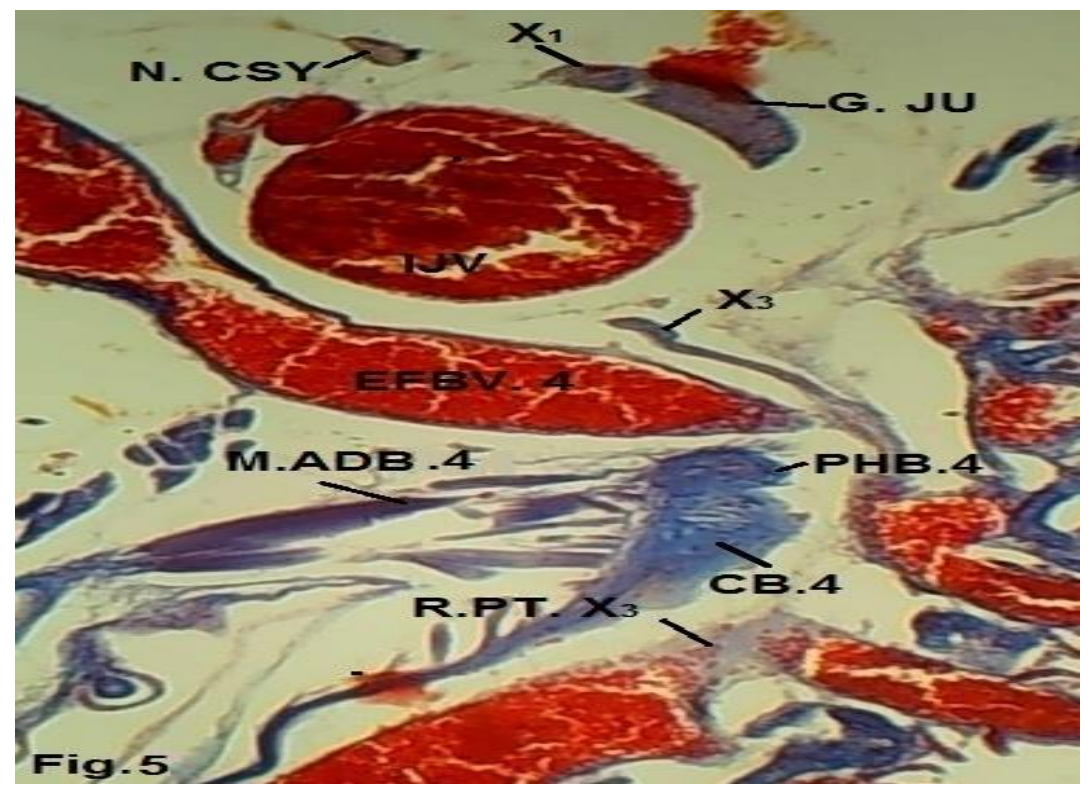

Fig. 5:- Photomicrograph of a part of a transverse section of Alticus kirkii magnusi passing in the postotic region showing the origin of the first branchial vagal trunk from the jugular ganglion, the anterior part of the jugular ganglion the third branchial vagal trunk and its posttrematic ramus. X 60

BO: Basioccipital bone, CB.4: Fourth ceratobranchial cartilage, EO: Exoccipital bone, EFBV.4: Fourth efferent branchial vessel G.JU: Jugular ganglion, HK: Head kidney, IJV: Internal jugular vein, LD.X: Lateral division of vagal nerve, M.ADB.4: Fourth adductor arcus branchialis muscle M.LAB.4: Fourth levator arcus branchialis muscle, MD.X: Median division of vagal nerve, N.CSY: Cranial sympathetic nerve,N.LAB.4: Nerve for the fourth levator arcus branchialis muscle, PHB.4: Fourth pharyngeobranchial cartilage, PLLN: Posterior lateral line nerve, R.PT. $\mathrm{X}_{3}$ : Ramus posttrematicus of the third branchial vagal trunk, TV:Truncus visceralis, $\mathrm{X}_{1}$ : First branchials vagal trunk, $X_{3}$ : Third branchial vagal trunk.

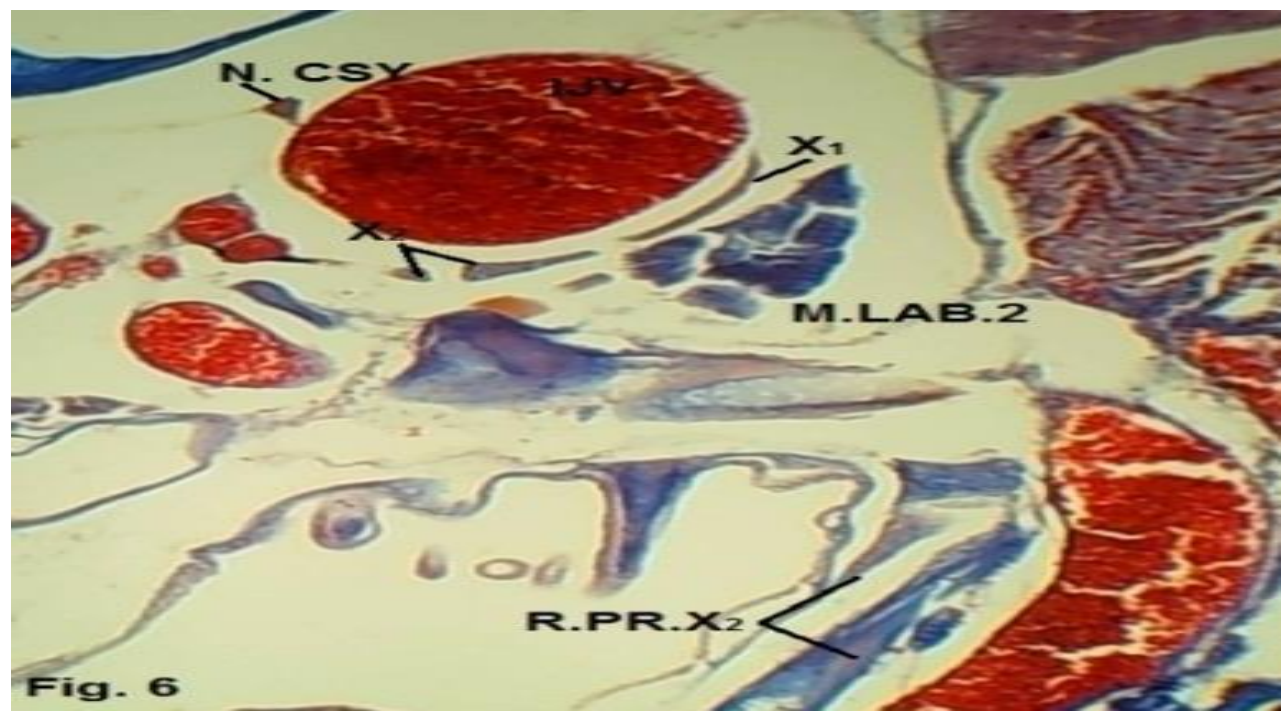

Fig. 6:- Photomicrograph of a part of a transverse section of Alticus kirkii magnusi passing in the postotic region illustrating the first and the second branchial vagal truncus, the posttrematic ramus of the second branchial vagal trunk. X 60. 


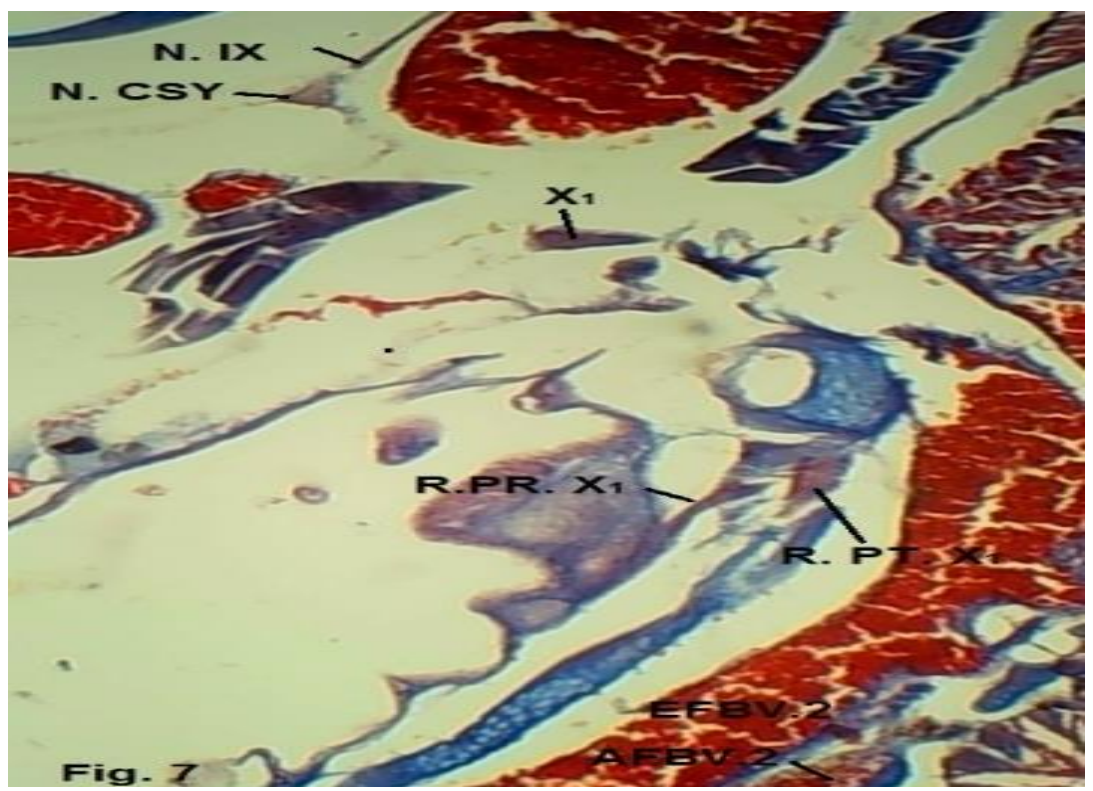

Fig. 7:- Photomicrograph of a part of a transverse section of Alticus kirkii magnusi passing in the postotic region demonstrating the first branchial vagal trunk and its pre- and posttrematic rami. X 60 .

IJV: Internal jugular vein, M.LAB.2: Second adductor arcus branchialis muscle, $\quad$ N.IX: Nervus glossopharyngeus, N.CSY: Cranial sympathetic nerve, R.PR.X ${ }_{1}$ : Ramus Pretrematicus of the first branchial vagal trunk, R.PR.X. Ramus Pretrematicus of the second branchial vagal trunk, R.PT. $X_{1}$ : Ramus posttrematicus of the first branchial vagal trunk, $\mathrm{X}_{1}$ : First branchial vagal trunk, $\mathrm{X}_{2}$ :Second branchial vagal trunk.

To few nerves to the gill filament. More forwards, it becomes dorsal to the efferent blood vessel and ventral to the ceratobranchial bone. Thereafter, the posttrematic ramus (Fig. 1, R. PT. $\mathrm{X}_{1}$ ) gives off three fine branches to the gill filaments and two nerves to the gill rackers. More forwards, the posttrematic ramus gives off a nerve to the connective tissue and gill filament. Shortly forwards, the posttrematic ramus enters the isthmus. In the isthmus, the posttrematic ramus runs anteromedially passing ventromedial to the ceratobranchial bone. Here, it gives rise to a branch to the roof of the isthmus. This branch ramifies to innervate the epithelium covering the isthmus and the taste buds in this region (Fig. 1, Nn.TB). Thereafter, the posttrematic ramus gives off a motor nerve to the second obliquus ventralis muscle (Fig. 1, N. OV.2) and a sensory one to the taste buds and epithelium of the isthmus. Finally, it runs anteromedially to end as fine nerves between the follicles of the thyroid gland (Fig. 1, N. THG).

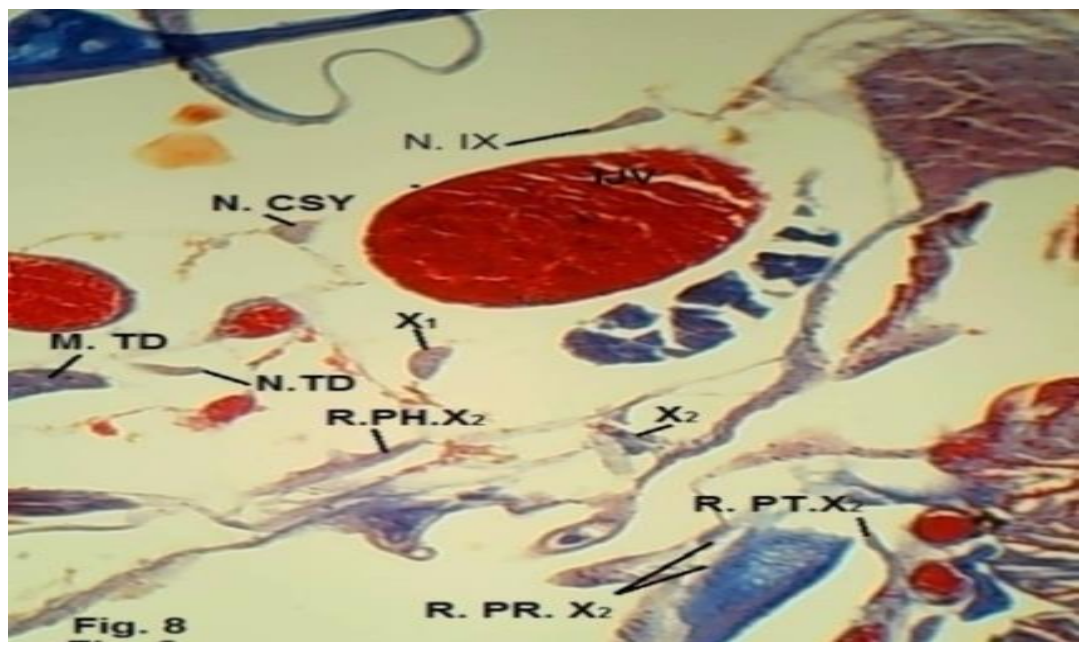

Fig. 8:-Photomicrograph of a part of a transverse section of Alticus kirkii magnusi passing in the postotic region showing the first and second branchial vagal truncus, the rami pharyngeus, pretremticus and posttrematicus of the second branchial vagal trunk and the transverses dorsalis muscle nerve.X 60 


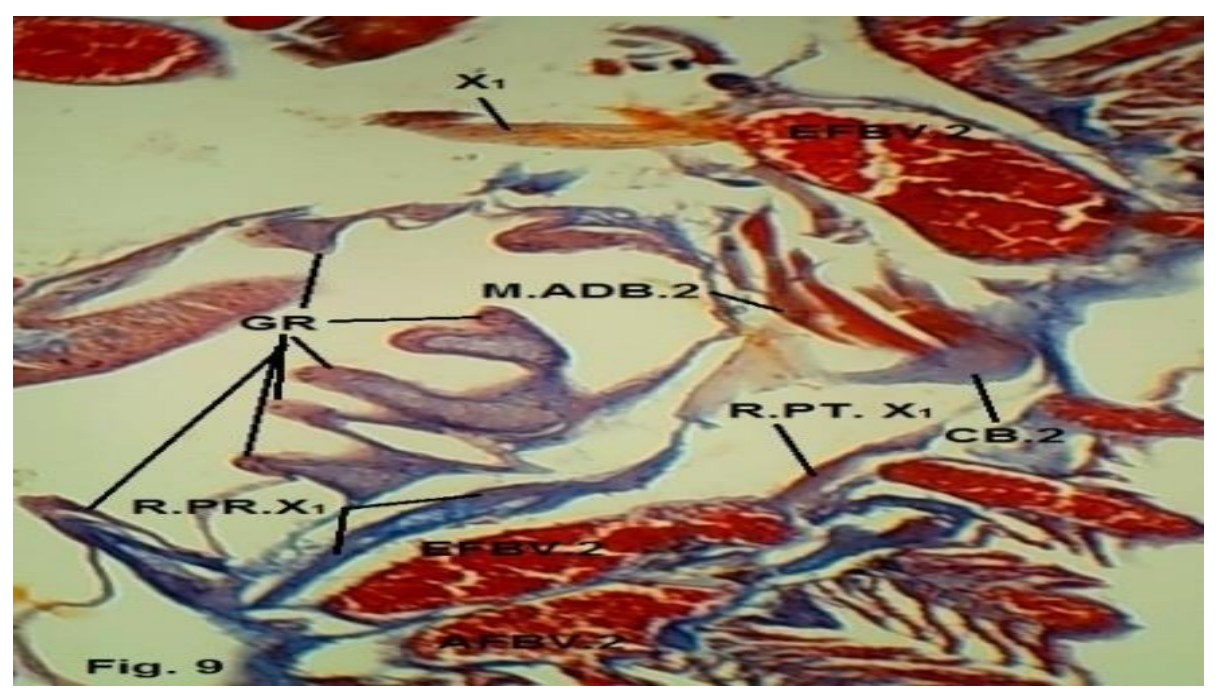

Fig. 9:-Photomicrograph of a part of a transverse section of Alticus kirkii magnusi passing in the postotic region showing theentrance offirst branchial vagal trunk into the second holobranch and its pretremtic and posttrematic rami. X 60 .

\begin{abstract}
AFBV.2:-
Second afferent branchial vessel, CB.2: Second ceratobranchial cartilage, EFBV.2: Second efferent branchial vessel, GR: Gill rackers, IJV: Internal jugular vein, M.ADB.2: Second adductor arcus branchialis muscle, M.TD: Transversus dorsalis muscle, N.CSY: Cranial sympathetic nerve, N.IX: Nervus glossopharyngeus, N.TD: Nerve for transversus dorsalis muscle, R.PH.X ${ }_{2}$ : Ramus pharyngeus of the second branchial vagal trunk, R,PR.X 1 : Ramus Pretrematicus of the first branchial vagal trunk, R,PR.X $\mathrm{X}_{2}$ : Ramus Pretrematicus of the second branchial vagal

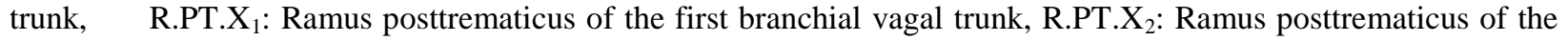
second branchial vagal trunk, $\mathrm{X}_{1}$ : First branchial vagal trunk, $\mathrm{X}_{2}$ : Second branchial vagal trunk.
\end{abstract}

\title{
Second Branchial Vagal Trunk " $\mathrm{X}_{2}$ ":-
}

Directly after its separation from the ventral end of the jugular ganglion, the second trunk (Figs. $\left.1 \& 6, \mathrm{X}_{2}\right)$ extends forwards passing ventrolateral to the dorsal bundle of the medial vagal division and lateral to the internal jugular vein. After a short forward course, it receives a branch from the dorsal bundle of the medial vagal division (Fig. 1). After that, it runs anteromedially, passing ventral to the internal jugular vein, medial to the first vagal branchial trunk and dorsal to the second pharyngeobranchial cartilage (Fig. 6, $\mathrm{X}_{2}$ ). Here, it gives off two successive branches; one to the transverses dorsalis muscle (Fig. $1 \& 8, \mathrm{~N}$. TD) and the other to the third levator arcus branchialis muscle (Fig. 1, N. LAB. 3). Again, after a short cephaled distance, the main trunk gives off the ramus pharyngeus (Fig. 1\& 8, R. PH. $\mathrm{X}_{2}$ ).

\section{The Ramus Pharyngeus $\mathrm{X}_{2}$ :-}

After its separation from the second vagal branchial trunk, the ramus pharyngeus (Figs. 1\&8, R. PH. $\mathrm{X}_{2}$ ) runs medially to become dorsal to the pharynx. Here, it gives rise to a ventral branch which, immediately ramifies in the epithelial lining of the lateral part of the pharyngeal roof (Fig. 1, N. EP). The main ramus continues anteromedially for a distance, then, it ramifies in the dorsal side of the pharynx to innervate its epithelium and the taste buds in this region (Fig. 1, N. EP).

Shortly forwards, the main trunk gives raise a ventral motor nerve to the third adductor arcus branchialis muscle (Fig. 1, N. ADB. 3). Thereafter, the main trunk divides into a ventromedial pretramatic ramus (Figs. 1, 6\&8, R. PR. $\mathrm{X}_{2}$ ) and a dorsolateral ramus posttrematicus (Figs. 1\&8, R. PT. $\mathrm{X}_{2}$ ).

\section{Ramus Pretrematicus $\mathrm{X}_{2}$ :-}

The pretrematic ramus (Figs.1, 6\&8, R. PR. $\mathrm{X}_{2}$ ) runs posteroventrally passing lateral to the pharyngobranchial bone and medial to both the third levator arcus branchialis muscle and then to the third epibranchial bone. Thereafter, it turns forwards running medial to the later bone and dorsomedial to the ceratobranchial bone just anterior to their articulation. Here, it gives off three fine nerves to the gill rackers (Fig. 1, Nn. GR). More forwards, it gives off a dorsal branch to the gill rackers. Thereafter, this ramus shifts ventromedially giving rise to two successive nerves to 
the gill rakers (Fig. 1, Nn. GR). More and more forwards, the pretrematic ramus $\mathrm{X}_{2}$ continues in the same position and finally it ramifies into small nerves that end in the gill rackers and the epithelium of the third holobranch (Fig. 1, Nn. GR).

\section{Ramus Posttrematicus $\mathrm{X}_{2}$ :-}

The ramus posttrematicus $\mathrm{X}_{2}$ (Figs. $1 \& 8, \mathrm{R}$. PT. $\mathrm{X}_{2}$ ) runs forwards extending ventromedial to the internal jugular vein, medial to the first vagal branchial trunk and dorsal to the epibranchial bone. Thereafter, it shifts ventrolaterally passing dorsolateral to the third efferent branchial vessel and ventromedial to the third levator arcus branchialis muscle to enter the third holobranch. Here, it gives off a motor branch for the third adductor branchialis muscle (Fig. 1, N. ADB. 3) and a lateral branch for the dorsal gill filaments. Thereafter, it continues backwards for a distance and then turns its course anteroventrally, extending ventrolateral, ventral and ventromedial to both the third efferent branchial vessel and the third ceratobranchial bone. Here, it gives off branches to the gill filaments (Fig. 1, Nn. GF). Thereafter, the ramus posttrematicus $\mathrm{X}_{2}$ gives off two lateral nerves to the gill filament (Fig. 1, Nn. GF). More forwards, the ramus posttrematicus $\mathrm{X}_{2}$ (Fig. 1, R. PT. $\mathrm{X}_{2}$ ) gives off another three nerves to the gill filaments. Shortly cephaled, it enters the isthmus where, the third holobranch fuses with it. Here, the ramus posttrematicus $\mathrm{X}_{2}$ gives off two motor nerves; one enters and ends in the third obliquus ventralis muscle (Fig. 1, N.OV.3) and the second passes to the transversus ventralis muscle Fig. 1, N.TVE) where it achieves its final fate. Finally, this ramus ends in the epithelium covering the isthmus.

\section{Third Vagal Branchial Trunk $\mathrm{X}_{3}$ :-}

The third vagal branchial trunk arises from the anteroventral end of the jugular ganglion, just posterior to the origin of the second trunk, as previously mentioned (Fig. 1, $\mathrm{X}_{3}$ ). It runs forwards and fuses with the lateral nerve of the ventral bundle of the vagal medial divison.

This trunk runs forwards in ventromedial direction passing medial to the fourth levator arcualis branchialis muscle and dorsal to the fourth holobranch, ventrolateral to the internal jugular vein and ventromedial to the jugular ganglion (Fig. 5, $\mathrm{X}_{3}$ ). Here, it gives off a lateral motor nerve which runs forwards to end in the fourth levator arcus branchialis muscle (Fig. 1, N. LAB. 4). Shortly anterior, the third vagal branchial trunk divides into medial division representing the rami pharyngeus and pretrematicus and a lateral ramus posttrematicus (Fig. 1, R. PH.X 3 \& R. PT. $\mathrm{X}_{3}$ ). A separate ramus pretremticus appears to be lacking.

\section{Ramus Pharyngeus $\mathrm{X}_{3}$ :-}

This ramus (Fig. 1, R. PH. $\mathrm{X}_{3}$ ) runs forwards in the medial direction passing ventral to the fourth efferent branchial vessel and dorsal to the fourth levator arcus branchialis muscle. After a course, it reaches the dorsolateral corner of the pharynx. Here, it gives off two branches to the epithelial mucosa of roof of the pharynx and the pharyngeal teeth.

After that, the ramus pharyngeus,runs anteroventrally for a short distance extending lateral to the pharynx and medial to fourth adductor arcus branchialis muscle. Entering the holobranch, it runs forwards medial to the ceratobranchial cartilage and lateral to the pharyngeal cavity. Here, it ramifies and ends in the epithelium, the gill rackers and teeth of the holobranch (Fig. 1).

\section{Ramus Posttrematicus $\mathrm{X}_{\mathbf{3}}$ :-}

After its separation from the medial division, the ramus posttrematicus (Figs. 1\& 5, R. PT. $X_{3}$ ), runs anteriorly for short course gives off a motor nerve to the fourth adductor branchialis muscle (Fig. 1, N. ADB. 4). Thereafter, it enters the fourth holobranch, just dorsolateral to the fourth efferent branchial vessel and immediately posterior to the articulation of the fourth epi- and ceratobranchial bones. Here, it gives off fine branches to the dorsal gill filaments. Thereafter, it runs forwards ventrolateral to the fourth ceratobranchial bone and lateral to the efferent branchial vessel, giving rise to several branches to the gill filaments (Fig. 1, Nn. GF). Shortly forwards, it becomes ventral to the ceratobranchial cartilage and lateral to the efferent blood vessel. Here, it gives off two branches to the epithelial lining of pharynx. More forwards, this ramus enters isthmus and gives raise a dorsal nerve. This nerve extends dorsolateral to the fourth obliquus ventralis muscle, and ramifies into several fine branches that end in the epithelium and the ventral oral taste buds of the isthmus. Finally, the main ramus extends medially to enter and end in the fourth obliquus ventralis muscle (Fig. 1, N. OV. 4). 


\section{Discussion:-}

In Alticus kirkii studied, the nervus vagus originates from the mid-lateral side of the medulla oblongata by a single stout root that is distinctly separated from the root of the posterior lateral line nerve. The same result is recorded in Menidia (Herrick, 1899), Parasilurus asotus (Atoda, 1936), Lampanyctus leucopsarus (Ray, 1950), Pseudorhombus arsius (Marathe, 1955), Mystus seenghala (Mithel, 1964), Ctenopharyngodon idellus (Dakrory, 2000), Mugil cephalus (Hussein, 2010; Dakrory and Hussien, 2011), Hypophthalmichthys molitrix (Taha, 2010), Gambusia affinis affinis (Mattar, 2012), Liza ramada (Ali, 2012) and in Liza aurat (Al-Harthi, 2016). On the other hand, it has been found that, the nervus vagus originates from the medulla oblongata by two roots, anterior and a posterior in both Tilapia zillii (Dakrory \&Ali, 2006) and in Oreochromis niloticus (Almalki, 2017). Three roots for the nervus vagus were described by Harrison (1981) in Trichiurus lepturus. In Lepidotrigla (Allis, 1909), the vagus nerve arises by three small anterior rootlets and a main posterior root. Four rootlets were found in Polycentrus schomburgkii (Freihofer, 1978), and five in Latimeria chalumnae (Northcutt et al., 1978) and Gnathonemus petersii (Lazar et al., 1992). The nerve in question arises by several rootlets in Amia calva and Scomber scomber (Allis, 1897 \& 1909 , respectively) and Polypterus senegalus (Piotrowski and Northcutt, 1996) and by twenty rootlets in Polyodon (Norris, 1925). In this respect, the multiplicity of rootlets appears to be of common occurrence and may be a general rule, among teleosts according to Stannius (1849). The presence of a single root for the nervus vagus appears to be advanced character in bony fishes.

Among cartilaginous fishes, Norris and Hughes (1920) in Squalus acanthias, stated that there are thirty or more rootlets for the nervus vagus. Five rootlets for this nerve were found in the cartilaginous fishes studied by Gohar and Mazhar (1964). In the skate, Raja eglanteria (Sperry and Boord, 1992\& 1993), the vagus nerve arises as a series of superficial rootlets, the number and spacing of which vary considerably, not only among different specimens but also on the two sides of the same specimen. In this respect, Edgeworth (1935) stated that the rootlets of the nervus vagus in cartilaginous fishes vary from two to thirty; the most anterior of which are sensory forming the posterior lateral line nerve, while the most posterior ones are exclusively motor. In Rhinobatus halavi, the nervus vagus, including the posterior lateral line nerve arises by many rootlets (18-24 rootlets) as mentioned by Dakrory (2000). In jawless fish Petromyzon Marinus, the nerve in question has a single root (Barreiro-Iglesias, A., etal, 2008).

Among Amphibia, the nervus vagus arises by two roots as mentioned by Gaupp (1911), Soliman and Mostafa (1984) and Shaheen (1987). However, Wake et al. (1983) stated that the nervus vagus arises by three major and minor rootlets in the amphibians he studied.

In the blenniid species studied, the vagus nerve has a proximal (medial) intracranial glanglion (the ganglion of the intracranial dorsal cutaneous vagal ramus) and a distal (lateral) jugular (epibranchial) ganglion which is located extracranially. In most bony fishes, the nervus vagus has a proximal intracranial glanglion and three distal epibranchial ganglia (jugular ganglion) which are located extracranially. This was confirmed by Allis (1897, 1903, 1909) in Amia calva, Scomber scomber and Lepidotrigla, respectively, Atoda (1936) in Parasilurus asotus, Ray (1950) in Polycentrus schomburgkii, Northcutt and Bemis (1993) in Latimeria chalumnae, Piotrowski and Northcutt (1996) in Polypterus senegalus, Dakrory (2000) in Ctenopharyngodon idellus, Ali (2005), Dakrory and Ali (2006) in Tilapia zilli, Taha (2010) in Hypophthalmichthys molitrix, Hussein (2010) and Dakrory and Hussien (2011) in Mugil cephalus, Mattar( 2012) in Gambusia affinis affinis, Al-Harthi (2016) in Liza auratand byAlmalki (2017) in Oreochromis niloticus.

On the other hand, there is no medial ganglion for the nervus vagus among Chondrichthes (Cole, 1896; Norris and Hughes, 1920; Chandy, 1955; Sperry and Boord, 1993; Dakrory, 2000).

In cyclostomes, there is no medial sensory ganglion the hagfishes (Lindström, 1949). There is only one distal (lateral) jugular (epibranchial) ganglion, which is fragmented into several ganglia and scattered ganglion cells in Eptotretus stoutii and Myxine glutinosa (Braun, 1998) and in lampreys by Johnston (1905 \& 1908a), Wicht (1996) and Kuratani et al. (1997). In prolarvae, the vagal nerve shows two epibranchial ganglia situated dorsal to pharyngeal pouches 4 and 5, respectively (Barreiro-Iglesias, et al., 2008).

In Alticus kirkii studied, the proximal (medial) ganglion is associated with the intracranial dorsal cutaneous vagal ramus, which arises from this ganglion as two branches. A ventrolateral branch and an anterodorsal one, which carries general somatic sensory fibres to the skin covering the postotic region of the skull. This was the same in 
Menidia (Herrick, 1899), Scomber scomber (Allis, 1903), Ctenopharyngodon idellus (Dakrory, 2000) and in Tilapia zillii (Ali, 2005; Dakrory and Ali, 2006).

Among Amphibia, a dorsal cutaneous vagal ramus is found in salamanders (Coghill, 1902; Northcutt, 1992). And not recorded in Anura (Soliman and Mostafa, 1984; Shaheen, 1987; Barreiro-Iglesias, et al., 2008).

The intracranial dorsal cutaneous vagal ramus in Alticus kirkii studied carries general "cutaneous" somatic sensory fibres. This agrees very well with the description of Allis (1897, 1903 \& 1909) in Amia calva, Scomber scomber and Lepidotrigla, respectively, Herrick (1899) in Menidia, Norris (1925) in Acipenser, Lepidosteus and Amia, Freihofer (1963 \& 1978) in Atherinops affinis and Polycentrus schomburgkii, respectively, Piotrowski and Northcutt (1996) in Polypterus senegalus, Dakrory (2000) in Ctenopharyngodon idellus, Ali (2005), Dakrory and Ali (2006) in Tilapia zilli, Taha (2010) in Hypophthalmichthys molitrix, Hussein (2010) and Dakrory and Hussien (2011) in Mugil cephalus, Mattar( 2012) in Gambusia affinis affinis, Al-Harthi (2016) in Liza auratand byAlmalki (2017) in Oreochromis niloticus.Such ramus was not found in Protopterus annectens Pinkus (1895), Lampanyctus leucopsarus (Ray, 1950) and Latimeria chalumnae (Northcutt and Bemis, 1993). Northcutt and Bemis (1993) stated that, in such cases, the postotic roof of the skull appears to be innervated by somatic sensory fibres from the facial nerve which anastomoses with the otic and/or supratemporal lateral line nerve.

In the bony fish studied, the distal or lateral vagal ganglion (jugular ganglion) is undivided. In many bony fishes, this ganglion is divided into a number of epibranchial ganglia. This ganglion is divided into three epibranchial ganglia; one for each the first and the second branchial vagal trunks and the third for the last branchial and the truncus visceralis in Lampanyctus leucopsarus (Ray, 1950), Polycentrus schomburgkii (Freihofer, 1978) and in Tilapia zilli (Ali, 2005; Dakrory and Ali, 2006). On the other hand, Herrick (1901) found that the lateral vagal (epibranchial) ganglion is divided into two parts only; one epibranchial and one intestinal (visceralis) in Argyropelecus hemigymnus. Also, Allis (1903) stated that, only the first epibranchial ganglion is separated, while the others are more or less fused in Scomber scomber. In Cyclothone acclinidens (Gierse, 1904), separate ganglia were described for the first two branchial trunks but the third branchial trunk was found to lack a ganglion entirely. Also, Polypterus senegalus has only two lateral epibranchial vagal ganglia (Piotrowski and Northcutt, 1996). However, the lateral vagal ganglion is divided into four epibranchial ganglia, one for each branchial vagal trunk, and one visceral ganglion for the truncus visceralis in Amia calva by Allis (1897), in Menidia by Herrick (1899), in Parasilurus asotus by Atoda (1936), in Pseudorhombus arsius by Marathe (1955), in Trichiurus lepturus by Harrison (1981), in Cyprinus carpio by de Graaf (1990) and in Ctenopharyngodon idellus by Dakrory (2000).

In cartilaginous fishes, there are four epibranchial ganglia and one visceral ganglion for the truncus visceralis. This is the case found in cartilaginous species studied by Shore (1889), Cole (1896), Chandy (1955), Sperry and Boord (1993) and by Dakrory (2000).

In the current study, the first and a large parts of each the second and third branchial vagal trunks as well as the visceral trunk arise from the nervus vagus as a large common division, while other parts of the second and third branchial vagal trunks originate as the second division from the main vagal nerve. However, in Ctenopharyngodon idellus by Dakrory (2000), the first and second branchial trunks arise as a common nerve, while the third and fourth ones, together with the visceral trunk originate at the same point from the main vagal nerve.

In this respect, Atoda (1936), Dalela and Jain (1968) and de Graaf (1990) found that all the branchial vagal trunks arise at the same point in Parasilurus asotus, Clarias batrachus and Cyprinus carpio, respectively. In Mastacembelus armatus (Bhargava, 1959), there are two trunks arising from the vagal ganglion; one innervating the viscera and the other splits into the four branchial nerves. However, two dorsal and three ventral trunks arise from the vagal mass in Amphipnous cuchia (Saxena, 1967).

The three branchial vagal rami and the ramus intestinalis in Chimaera manstrosa have a separate origin from the brain and each possesses its own independent ganglion (Cole, 1896). Ray (1950) mentioned that the widespread appearance of separate epibranchial ganglia, particularly, among those fishes which are generally regarded as primitive forms, suggests that this condition represents the basic pattern, from which specialization has progressed along the lines of fusion or reduction in the total number of ganglia. As already indicated, the same may occur in the vagal roots. Thus the nervus vagus may be considered as representing not one, but three or possibly four, or even more fused nerves. Comparing the case in different fishes, the same author added that the roots might have been 
fused first and that subsequent distal progression of fusion happened in the ganglia of the more specialized forms. According to Ray's sight the condition in this study considered to be a high advances due to the presence of one root and one ganglion.

There is no ramus opercularis vagus in the blenniid fish of this study. It is also not mentioned in Lampanyctus leucopsarus (Ray, 1950), Trichiurus lepturus (Harrison, 1981), Polypterus senegalus (Piotrowski and Northcutt, 1996), Ctenopharyngodon idellus (Dakrory, 2000), Tilapia zillii (Ali, 2005), Hypophthalmichthys molitrix (Taha, 2010), Mugil cephalus (Hussien, 2010; Dakrory and Hussien, 2011), Gambusia affinis affinis (Mattar, 2012), Liza ramada (Ali, 2012), Liza aurat (Al-Harthi, 2016) and in Oreochromis niloticus (Almalki, 2017). Such ramus was mentioned by Herrick (1899) in Menidia and Freihofer (1978) in Polycentrus schomburgkii.

Typically, each of the branchial vagal trunks of fishes is divided into rami pharyngeus, pretrematicus and posttrematicus. In the present study, the first branchial vagal trunk lacks ramus pharyngeus and the third trunk lacks the ramus pretrematicus. On the other hand, in the bony fish, Cyclothone acclinidens (Gierse, 1904), the ramus pharyngeus was found to be completely lacking. Ray (1950) stated that there is only a ramus pharyngeus and a ramus pretrematicus for the third branchial vagal trunk, while the ramus posttrematicus is reduced in Lampanyctus leucopsarus. Among cartilaginous fishes, the last or fourth ramus posttrematic was found to want in the batoid Raja eglanteria (Sperry and Boord, 1993).

In the blenniid species studied both the pretrematic and posttrematic rami of the branchial vagal trunks are undoubled. Again, the pretrematic rami are not double in the shark Squalus acanthias (Norris and Hughes, 1920), in the dipnoan Protopterus annectens (Pinkus, 1895), Menidia (Herrick, 1899), Latimeria chalumnae (Northcutt and Bemis, 1993) and Ctenopharyngodon idellus (Dakrory, 2000), Gambusia affinis affinis (Mattar, 2012), Liza ramada (Ali, 2012) and inLiza aurat (Al-Harthi, 2016). On the other hand, the pretrematic rami of the branchial vagal trunks are doubling (anterior and posterior) in Acipenser, Lepidosteus and Amia (Norris, 1925), Lampanyctus leucopsarus (Ray, 1950), Cyprinus carpio (de Graaf, 1990), Polypterus senegalus (Piotrowski and Northcutt, 1996), Tilapia zillii (Ali, 2005; Dakrory and Ali, 2006), Hypophthalmichthys molitrix (Taha, 2010), Mugil cephalus (Dakrory and Hussien, 2011) and in Oreochromis niloticus (Almalki, 2017).

Regarding posttrematic rami, in the species studied, the posttrematic rami of the branchial vagal trunks are undoubled. The same case, was described by Pinkus (1895) in the lungfish Protopterus annectens, Dakrory (2000) in Ctenopharyngodon idellus, Ali (2005) and Dakrory and Ali (2006) in Tilapia zilli.. On the other hand, these rami are doubled in Squalus acanthias (Norris and Hughes, 1920) and in the bony fishes, Menidia (Herrick, 1899), Acipenser, Lepidosteus and Amia (Norris, 1925), Cyprinus carpio (de Grraf, 1990), Latimeria chalumnae (Northcutt and Bemis, 1993) and Polypterus senegalus (Piotrowski and Northcutt, 1996).

In the present study, the first vagal trunk receives a sympathetic branches arising from the cranial sympathetic nerve. In this respect, the posttrematic ramus of the first branchial vagal trunk receives a sympathetic branch arising from the sympathetic vagal ganglion in Ctenopharyngodon idellus (Dakrory, 2000). The first and third epibranchial ganglia receive sympathetic branches arising from the sympathetic vagal ganglion inLiza ramada (Ali, 2012), Liza aurat (Al-Harthi, 2016) and in Oreochromis niloticus (Almalki, 2017). A connection between the nervus vagus and the sympathetic ganglion is present in Pseudorhombus arsius (Marathe, 1955) and Takifugu niphobles (Funakoshi et al., 1996, 1997). Ray (1950) stated that the sympathetic trunk has a connection with one of the vagal nerves arising in the jugular foramen by a minute branch in Lampanyctus leucopsarus.

In this study, the nervus vagus carries special visceral sensory fibres for the taste buds and general ones for the lining epithelium of the pharynx and visceral arches. They carry, also, branchiomeric motor (visceromotor) fibres for the branchial muscles. In addition to these fibres, the nervus vagus carries also, general somatic sensory fibres for the skin covering the roof of the postotic region of the skull, and vegetative fibres (parasympathetic) for the blood vessels, thyroid gland and the muscles of the gill filaments.

In this study, the somatic sensory fibres of the vagus nerve are included in a separate nerve; the intracranial dorsal cutaneous vagal ramus which passes to the skin covering the postotic region of the skull. This was discussed previously. 
The visceral sensory fibres are found in all the rami of the nervus vagus studied except the intracranial dorsal cutaneous vagal ramus. The pharyngeal and pretrematic rami carry only visceral sensory, whereas, the posttrematic rami carry, in addition to the visceromotor fibres, visceral sensory ones. The visceral sensory fibres of the vaugs, glossopharyngeal and facial nerves innervate the oropharyngeal epithelium and their taste buds. This means that the gustatory fibres, in fishes, are carried by three cranial nerves; the facial, glossopharyngeal and vagal nerves. This was confirmed by Herrick (1944) and Kinnamon (1987) in fishes and tetrapods. About the origin or source of the gustatory components of these three nerves, Landacre (1910) and Northcutt (1997) mentioned that these components have been thought to arise from a separate epibranchial neurogenic placode.

In lampreys, the gustatory fibres are carried by the nervi glossopharyngeus and vagus only. Such fibres are completely lacking from the facial nerve (Johnston, 1905 and 1908b; Finger and Morita, 1985; Finger, 1987; Braun, 1998).

\section{References:-}

1. Aizawa, M., \& Doiuchi, R. (2013): Blenniidae. In: Nakabo T (ed) Fishes of Japan with pictorial keys to the species, 3rd edn. Tokai University Press, Tokyo, pp 1295-1324.

2. Alavi-Yeganeh, M.S., Sharifiniya, M., Ghasemzadeh, J., Amoeii, M. \&Mousavi-Sabet, S.H. (2018): Lengthweight and length-length relationships of three Blenny species from the Persian Gulf and the Gulf of Oman. Journal of Applied Ichthyology, 1-3.

3. Abou-Seedo, F.S. (1992): Abundance of fish caught by stake-traps (hadra) in the intertidal zone in Doha, Kuwait Bay. Journal of the University of Kuwait (Science), 19: 91-99.

4. Al-Harthi, D. A. (2016): Anatomical Studies on the Cranial Nerves of Liza aurata (Ostiechthyes - Mugilidae). M. Sc. thesis, Fac. Sci., TaifUniv., K.S.A.

5. Ali, H. M. (2012): Anatomical studies on the cranial nerves of fully formed embryonic stage of Liza ramada (Risso, 1827). M. Sci. Thesis, Fac. Sci., Helwan Univ., Egypt.

6. Ali, R.S. (2005): Comparative anatomical studies on the cranial nerves of the embryo of Tilapia zillii. Ph.D. Thesis, Fac. Sci., Helwan Univ., Egypt.

7. Ali, R.S., \& Dakrory, A.I. (2008): Anatomical studies on the cranial nerves of Alticus kirkii magnosi. I. The eye muscle nerves and the ciliary ganglion. Egypt. J. Zool., 51: 221-239.

8. Allis, E.P. Jr. (1897): The cranial muscles and cranial and first spinal nerves in Amia calva. J. Morph., 12: 487808.

9. Allis, E.P. Jr. (1903): The skull, and the cranial and first spinal muscles and nerves in Scomber scomber. J. Morph., 18: 45-310.

10. Allis, E.P. Jr. (1909): The cranial anatomy of the mail-cheeked fishes. Zool. (Stuttgart), 22: 1-219.

11. Allis, E.P. Jr. (1922): The cranial anatomy of polypterus, with special reference to Polypterus bichir. J. Anat., 56: 189-294.

12. Al-Malki, D. A. (2017): Anatomical Studies on the Cranial Nerves of Orechromis niloticus (Ostiechthyes Cichlidae). M. Sc. thesis, Fac. Sci., Taif Univ., K.S.A.

13. Atoda, K. (1936): The innervation of the cranial nerves of the cat-fish, Parasilurus asotus L. Sci. Rep. Tohoku Univ., 11: 91-115.

14. Barreiro-Iglesias,A., Gómez-López, M. P., Anadó, R.\& Rodicio, M. C. (2008): Early Development of the Cranial Nerves in a Primitive Vertebrate, the Sea Lamprey, Petromyzon Marinus L.J.,Zool., 1: 37-43.

15. Bauchot, R., Thomot, A. \&Bauchot, M.L. (1989): The eye muscles and their innervation in Chaetodon trifasciatus (Pisces, Teleostei, Chaetodontidae). Enviro. Biol. of fishes., 25 (1-3): 221-233.

16. Bhargava, H. (1959): The morphology of the chondrocranium of Mastacembelus armatus (Cuv. \& Val.). J. Morph., 104 (2):237-260.

17. Braun, C.B. (1998): Schreiner organs: A new craniate chemosensory modality in hagfishes. J. Comp. Neurol., 392: 135-163.

18. Breder, C. M., J. \& Gresser, E. B. (1940): The eye structure of the four-eyed blenny, Dialommus fuscus Gilbert. New York Zoological Society, 24,239-244.

19. Breder, C.M., \& Rosen, D.E. (1966):Modes of reproduction in fishes. T.F.H. Publications, Neptune City, New Jersey.

20. Brown, C. R., Gordon, M. S. \& CHIN, H. G. (1991): Field and laboratory observations on microhabitat selection in the amphibious Red Sea rockskipper fish, Alticus kirki (Family Blenniidae). Mar. Behav. Physiol. 19:1-13. 
21. Brown, C. R., Gordon, M. S. \& Martin, K. L. M. (1992): Aerial and Aquatic Oxygen Uptake in the Amphibious Red Sea Rockskipper Fish, Alticus kirki (Family Blenniidae). Copeia, (4): 1007-1013.

22. Chandy, M. (1955): The nervous system of the Indian sting-ray Dasyatisrafinesque (Trygon cuvier). J. Zool. Sci. India, 7 (1): 1-12.

23. Clark, H. W. (1936): The Templeton Crocker expedition of the California Academy of Sciences, 1932. No. 29. New and noteworthy fishes. Proceedings of the California Academy of Sciences,21;383-396.

24. Coghill, G.E. (1902): The cranial nerves of Amblystoma tigrinum. J. Comp. Neurol., 12: 205-289

25. Cole, F.J. (1896): On the cranial nerves of Chimaera monstrosa (Linn., 1754); with a discussion of the lateral line system, and of the morphology of the chorda tympani. Trans. R. Soc. Edinb., 38: 631-680.

26. Curio, E. (1968): Some observations on the ' four-eyed ' blenny of the Gala'pagos Islands, Dialommus fuscus (Pisces: Clinidae). Notı'cias de Gala'pagos 12,13-17.

27. Dakrory, A.I. (2000): Comparative anatomical studies on the cranial nerves of Rhinobatus halavi (Class: Chondrichthyes) and Ctenopharyngodonidellus (Class : Osteichthyes). Ph.D. Thesis, Fac. Sci., Cairo Univ., Egypt.

28. Dakrory, A.I. (2003): The ciliary ganglion and its anatomical relations in

29. Some bony fishes. Egypt. J. Zool., 41: 1-13.

30. Dakrory, A. I.; Abdel-Kader, T. G.; Ali, R. S.; \& Mahgoub, A. F. (2018a): Innervation of the gill region of Garra tibanicaTrewavas, 1941 From Taif KSA. (Ostiechthyes- Cyprinidae). I-NERVUS GLOSSOPHARYNGEUS.SYLWAN., 162(4):104-137.

31. Dakrory, A. I.; Ali, H. M.; Ali, R. S. \& Hassan, M. M. (2018b): Eye-muscle nerves and ciliary ganglionof Garra tibanica Trewavas, 1941, (Osteichthyes-Cyprinidae) from Sayasid-Taif-KSA. Jokull J., 68 :193-216.

32. Dakrory, A.I. \& Ali, R.S. (2006): Comparative anatomical study on the cranial nerves of Tilapia zillii. The nervus glossopharyngeus. J. Egypt. Ger. Soc. Zool., 49(B): 1-18.

33. Dakrory, A.I; Ali, R.S. \& Issa, A.Z. (2012): Anatomical Studied on the Cranial Nerves of Liza Ramada (Family: Mugilidae) Nervus Glossopharyngeus. Life Science Journal, 9(2): 86 -93.

34. Dakrory, A.I. \& Hussein, A.K. (2011): Anatomical studies on the cranial nerves of Mugil cephalus (family : Mugilidae). nervus vagus. Aust. J. Basic \& Appl. Sci.; 5(12): 60-74.

35. Dalela, R.C. \& Jain, D.K. (1968): Studies on the cranial nerves of Clarias batrachus (Linn.). J. Agra Univ. Res., 17:107-114

36. De Graaf, P.J. (1990): Innervation pattern of the gill arches and gills of the carp (Cyprinus carpio). J. Morph., 206: 71-78.

37. Dejours, P. (1981): Principles of comparative respiratory physiology, 2d ed. North Holland Publishing, Amsterdam, The Netherlands.

38. Edgeworth, F.H. (1935): The cranial muscles of the vertebrates. Cambridge Univ. Press.

39. Finger, T.E. (1987): Gustatory nuclei and pathways in the central nervous system in T.E. Finger and W.L. Silver [Eds.] Neurobiology of Taste and Smell. New York: John Wiley and Sons, pp. 331-353.

40. Finger, T.E. \& Morita, Y. (1985): Two gustatory systems: Facial and vagal gustatory nuclei have different brain stem connections. Science, 227: 776-778.

41. Freihofer, W.C. (1963): Patterns of the ramus lateralis accessories and their systematic significance in teleostean fishes. Standford ichthyol.Bull.,8: 81-189.

42. Freihofer, W.C. (1978): Cranial nerves of a percoid fish, Polycentrus schomburgkii (Family: Nandidae), a contribution to the morphologyand classification of the order Perciformes. Occ. Pap. Calf. Acad. Sci.,128: 1-75.

43. Funakoshi, K.; Abe, T. \& Kishida, R. (1996): Direct projections from the spinal cord to the trigeminal sympathetic ganglion of the puffer fish, Takifugu niphobles. Neurosci. Lett., 213: 115-118.

44. Funakoshi, K.; Abe, T.; Rahman, S.M. \& Kishida, R. (1997): Contralateral projections by preganglionic neurons to the sympathetic trunk of the puffer fish, Takifugu niphobles. J. Autonom. Ner. Syst., 66: 94-96.

45. Gaupp, E. (1911): Über den N. trochlearis der urodelen und über die Austrittsstellung der Gehirnnerven aus dem Schädelraum im allgemeinen. Anat. Anz., 38:401-444.

46. Gierse, A.F. (1904): Untersuchungen über das Gehirn und die Kopfnerven von Cyclothone acclinidens. J. Morph., 32: 602-688.

47. Gilbert, C. H. (1891): A supplementary list of fishes collected at the Galapagos Islands and Panama, with descriptions of one new genus and three new species. Proceedingsof the U.S. Nature Museum 13: 449-455.

48. Gohar, H.A.F. \& Mazhar, F.M. (1964): The internal anatomy of Selachii from the North-Western Red Sea. Bubl. Mar. Biol. Sta. Ghardaqa, Red Sea, 13: 145-240.

49. Graham, J. B. (1976): Respiratory adaptations of marine air-breathing fishes, p. 165-187. In: Respiration of amphibious vertebrates. G. M. Hughes (ed.). Academic Press, London, England. 
50. Handrick, K. (1901): Zur Kenntnis des Nervensystems und der Leuchtorgane des Argyropelecus hemigymnus. Zoologica, 32: 1-68.

51. Harrison, G. (1981): The cranial nerves of the teleost Trichiurus lepturus. J. Morph., 167: 119-134.

52. Harabawy, A. S.A. \& Mekkawy, I. A. A. (2011): Skin Characteristics and Organization of the Air-breathing fish Alticus kirkii (Günther, 1969) along different body region. J., Biol., Sciences, 11(8): 466- 474.

53. Hastings, P.A. \& Springer, V.G. (2009): Recognizing diversity in blennioid fish nomenclature (Teleostei: Blennioidei). Zootaxa, 2120, 3-14.

54. Herrick, C.J. (1899): The cranial and first spinal nerves of Menidia: a contribution upon the nerve components of the bony fishes. J. Comp. Neurol., 9: 153-455.

55. Herrick, C.J. (1900): A contribution upon the cranial nerves of the codfish. J. Comp. Neurol., 10: 265-316.

56. Herrick, C.J. (1901): Cranial nerves and cutaneous sense organs of North

57. American siluroid fishes. J. Comp. Neurol., 11: 177-272.

58. Herrick, C.J. (1944): The cranial nerves: A review of fifty years. J. Sci. Lab. Denison Univ., 38: 41-51.

59. Howe, J. C. (1991): Egg surface morphology of Dialommus fuscus Gilbert (Pisces: Labrisomidae). Journal of Fish Biology 38, 149-152.

60. Hubbs, C. (1952): A contribution to the classification of the blennioid fishes of the family Clinidae with a partial revision of the eastern Pacific forms. StanfordIchthyological Bulletin 4,41-165.

61. Hughes, G. M. (1984): General anatomy of the gills, p. 1-72. In: Fish physiology, Vol. X, Part A. W. S. Hoar and D. J. Randall (eds.). Academic Press, London, England.

62. Hughes, G. M. \& Morgan, M. (1973): The structure of fish gills in relation to their respiratory function. Biol. Rev. 48:419-475.

63. Hussein, A.K. (2010): Anatomical studies on the cranial nerves of Mugil

64. cephalus (Family: Mugilidae). M.sc. Thesis, Fac. Sci., Cairo Uni., Egypt.

65. Johnston, J.B. (1905): The morphology of the vertebrate head from the view point of the functional divisions of the nervous system. J. Comp.Neurol., 15: 175-275.

66. Johnston, J.B. (1908a): Additional notes on the cranial nerves of Petromyzon. J. Comp. Neurol., 18: 569-608.

67. Johnston, J.B. (1908b): A note on the presence or absence of the glossopharyngeal nerve in myxinoids. Anat. Rec., 2: 233-239.

68. Kinnamon, J.C. (1987): Organization and innervation of taste buds, In T.E. finger and W.L. Silver (eds.): Neurobiology of Taste and Smell. New York: John Wiley \& Sons, pp. 277-297.

69. Kassem, M. A.; Thomot, A. \& Bauchot, R. (1988): The eye muscles and their innervation in the Gobiid fish Tridentiger trigonocephalus. Jap. J. Ichthyol., 35 (3): 341-350.

70. Kuratani, S.; Ueki, T.; Aizawa, S. \& Hirano, S. (1997): Peripheral development of the cranial nerves in a cyclostome, Lampetra japonica: Morphological distribution of nerve branches and the vertebrate body plan. J. Comp. Neurol., 384: 483-500.

71. Landacre, F.L. (1910): The origin of the cranial ganglia in Ameiurus. J. Comp. Neurol., 20: 309-411.

72. Lazar, G.; Szabo, T.; Libouban, S.; Ravaille-Veron, M.; Toth, T. \& Brändle, K. (1992): Central projections and motor nuclei of the facial, glossopharyngeal and vagus nerves in the mormorid fish Gnathonemus petersii. J. Comp. Neurol., 325: 343-358.

73. Lehn, C. (1918): Beiträge zur Kenntnis des primordial-schödels von Polypterus. Zeitsch.F. angewandte Anst. U. Konstitutions lehre, 2: 349- 408.

74. Lindstrom, T. (1949): On the cranial nerves of the cyclostomes with special reference on N. trigeminus. Acta Zool. (Stockh.), 30:315-348.

75. Maheswari, S.C. (1965): The cranial nerves of Mastacembelus armatus (Lacépède). Jpn. J. Ichthyol., 12(3/6): 89-98.

76. Marathe, V.B. (1955): The nervous system of Pseudorhombus arsius (H.B.). J. Bombay Univ., 23, B3: 60-73.

77. Martin, K. L. M. (2014): Theme and variations: amphibious air-breathing intertidal fishes. J Fish Biol 84:577602

78. Martin, K.L.M. \& Bridges, C.R. (1999): Respiration in water and air. In: M.H. Horn, K.L.M. Martin and M.A. Chotkowski (eds), Intertidal Fishes: Life in Two Worlds, pp. 54-78. Academic Press, San Diego.

79. Matter, S.F.E. (2012): Anatomical studies on the cranial nerves of fully formed embryonic stage of Gambusia affinis affinis(Baird \& Girard, 1853).M.Sci. Thesis. Fac. Sci. HelwanUniv. Egypt.Mehraban, H. \&Esmaeili, H.R. (2018): Comb-tooth blennies of the intertidal zones of Persian Gulf and Makran Sea: Morphology, taxonomy, distribution and conservation status (Blenniiformes: Blenniidae). Iranian Journal of Ichthyology 5(3): 192-211.

80. Mithel, M. (1964): The cranial nerves of sisorid catfish Bagarius bagarius. Copeia, 4: 673-678. 
81. Munk, O. (1970): The eye of the ' four-eyed' fish Dialommus fuscus (Pisces, Blennioidei, Clinidae). Videnskabelige Meddelelser Dansk Naturhistorisk Forening i Kjøbenhavn

82. 137,7-24.

83. Nakae, M. \& Sasaki, K. (2006): Peripheral nervous system of the ocean sunfish Molamola (Tetraodontiformes: Moidae). Ichthyol. Res., 53: 233-246.

84. Nelson, J.S.; Grande, T.C. \& Wilson, M.V. (2016): Fishes of the World. John Wiley \& Sons.

85. Nieder, J. (2001): Amphibious behaviour and feeding ecology of the four-eyed blenny (Dialommus fuscus, Labrisomidae) in the intertidal zone of the island of Santa Cruz (Galapagos, Ecuador). Journal of Fish Biology, 58:755-767

86. Norris, H.W. (1925): Observation upon the peripheral distribution of the cranial nerves of certain ganoid fishes (Amia, Lepidosteus, Polyodon,Scaphirhynchus and Acipenser). J. Comp. Neurol., 39: 345-432.

87. Norris, H.W. \& Hughes, S.P. (1920): The cranial, occipital and anterior

88. spinal nerves of the dogfish, Squalus acanthias. J. Comp. Neurol., 31:

89. 292-402.

90. Northcutt, R.G. (1992): Distribution and innervation of lateral line organs in the Axolotl. J. Comp. Neurol., 325: $95-123$.

91. Northcutt, R.G. (1997): Evolution of gnathostome lateral line ontogenies. J. Brain Behav. Evol., 50: 25-37.

92. Northcutt, R.G. \& Bemis, W.E. (1993): Cranial nerves of coelacanth, Latimeria chalumnae (Osteichthyes: Sarcoptergii: Actinistia), and Comparisons with other Craniata. Brain Behav.Evol.,42(Suppl. 1): 1- 76.

93. Paterson, N.F. (1939). The head of Xenopus laevis. Q.J. Micr. Sci., 81(II): 161-234.

94. Northcutt, R.G., Neary, T.J. \& Senn, D.G. (1978): Observations on the Brain of the Coelacanth Latimeria chalumnae: External Anatomy and Quantitative Analysis. J. Morph., 155: 181-192.

95. Pantin, C.F.A. (1946): Notes on microscopical technique for Zoologists. Cambridge, England: Cambridge, University Press.

96. Pinkus, E. (1895): Die Hirnnerven des Protopterus annectens. Morph. Arb., 4: 275-346.

97. Piotrowski, T. \& Northcutt, R.G. (1996): The cranial nerves of the Senegal bichir, Polypterus senegalus (Osteichthyes: Actinopterygii: Cladistia). Brain Behav.Evol., 47: 55-102.

98. Randall, J.E. (1995): Coastal fishes of Oman. University of Hawaii Press. Honolulu.

99. Ray, D.L. (1950): The peripheral nervous system of Lampanyctus leucopsarus. J. Morph., 87: 61-178.

100.Saxena, P.K. (1967): The cranial nerves of the mud eel Amphipnous cuchia. Acta. Anat., 67: $306-320$.

101.Shaheen, A.A. (1987): Anatomical studies on the cranial nerves of Bufo regularis Reuss. M.Sc. Thesis, Faculty of Science, El-Minia University, Egypt.

102.Shore, T.W. (1889): On the minute anatomy of the vagus nerve in selachians with remarks on the segmental value of the cranial nerves.J. Anat. Physiol., 3: 428-451.

103.Smith, J.L.B. (1959a): Gobioid fishes of the families Gobiidae, Periophthalmidae, Trypauchenidae, Taenioididae and Kraemeriidae of the western Indian Ocean. Ichthyological Bulletin 13: 185-225.

104.Smith, J.L.B. (1959b): Fishes of the families Blenniidaeand Salariidae of the western Indian Ocean. Ichthyological Bulletin 14: 227-252.

105.Smith-Vaniz, W.F.; Satapoomin, U. \& Allen, G.R. (2001): Meiacanthus urostigma, a new fangblenny from the northeastern Indian Ocean, with discussion and examples of mimicry in species of Meiacanthus (Teleostei: Blenniidae: Nemophini). Aqua Journal of Ichthyology and Aquatic Biology 5: 25-43.

106.Soliman, M.A. \& Mostafa, R.H. (1984): The cranial nerves of Bufo viridis (LAUR). The nervi Facialis, Acusticus, Glossopharyngeus and vagus.Bull. Fac. Sci. Cairo Univ., 52: 461-493.

107.Sperry, D.G. \& Boord, R.L. (1992): Central location of the motorneurons that supply the cucullaris (Trapecius) of the clearnose skate, Raja eglanteria. Brain Res., 582: 312-319.

108.Sperry, D.G. \& Boord, R.L. (1993): Organization of the vagus in Elasmobranchs: Its bearing on a primitive gnathostome condition. Acta Anat., 148: 150-159.

109.Springer, V.G. \& Williams, J.T. (1994): The Indo-West Pacific blenniid fish genus Istiblennius reappraised: a revision of Istiblennius, Blenniella, and Paralticus, new genus. Smithsonian Contributions to Zoology: 1-193

110.Stannius, H. (1849): Das peripherische Nervensystem der Fische, anatomisch und physiologisch untersucht. Rostock.

111.Stevens, J. K. \& Parsons, K. E. (1980): A fish with a double vision. Natural History, 89: 62-67.

112.Taha, F. K. (2010): Anatomical studies on the cranial nerves of the fish Hypophthalmichthys molitrix. M. Sci. Thesis. Fac.Sci.Cairo Univ. Egypt.

113.Trewavas, E. (1941): Fresh water fishes. Expedition to South-West Arabia, 1937-38. British Museum, Natura.1 History. 1(3), pp. 7-15, pIs. I, II.-London (Jarrold \& Sons Ltd.). 
114.Watson, W. (2009): Larval development in Blennies. In: Patzner, R., Goncalves, E., Hastings, P., \& Kapoor, B. (Eds.), The Biology of Blennies. CRC Press, Boca Raton, FL, pp. 309-350.

115.Wright, J.M.; Clayton, D.A. \& Bishop, J.M. (1990): Tidal movements of shallow water fishes in Kuwait Bay. Journal of Fish biology 37(6): 959-974. 